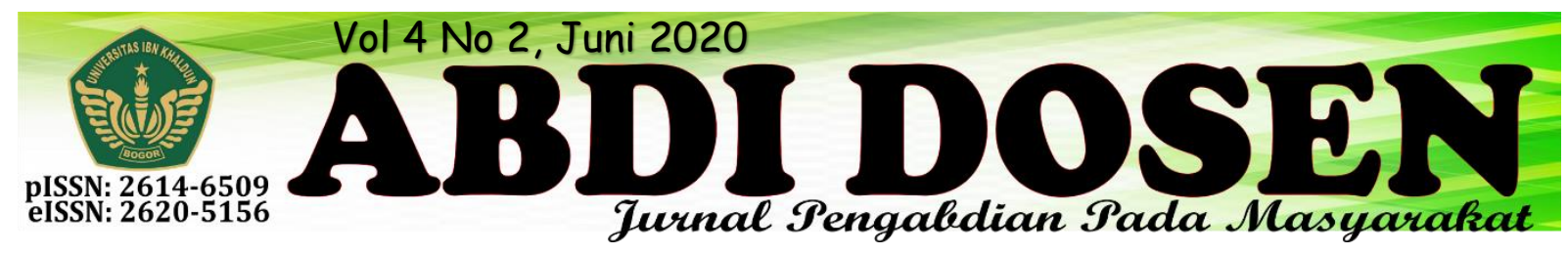

\title{
PEMBERDAYAAN MASYARAKAT DESA MELALUI PENGEMBANGAN POTENSI DAERAH DESA MEKARJAYA KECAMATAN CIGUDEG
}

\author{
Renea Shinta Aminda ${ }^{1}$, Rulhendri ${ }^{2}$, Supriana ${ }^{3}$ \\ renea_shinta@yahoo.com ${ }^{1}$ \\ rulhendri@gmail.com ${ }^{2}$ \\ supriana@gmail.com ${ }^{3}$ \\ Fakultas Ekonomi Universitas Ibn Khaldun ${ }^{1}$, Fakultas Teknik Universitas Ibn Khaldun², Mahasiswa KKN \\ Kelompok 39\&40 Tahun $2019^{3}$
}

\begin{abstract}
ABSTRAK
Kuliah Kerja Nyata merupakan kegiatan yang bertujuan untuk memahami kondisi dan mengetahui situasi yang terjadi di masyarakat serta memberikan solusi sebagai jalan pemecahan terhadap permasalahan yang ada untuk meningkatkan kesejahteraan masyarakat. Pelaksanaan kegiatan pengabdian kepada masyarakat ini dimulai dari bulan Agustus September 2019 di Desa Mekarjaya, Kecamatan Cigudeg. Observasi dilakukan dengan metode studi kasus menggunakan wawancara dan kuisioner sebagai instrumen dengan tujuan untuk mengetahui serta menganalisa kondisi, situasi, serta permasalahan di Desa Mekarjaya. Masyarakat di Desa Mekarjaya merupakan masyarakat yang beragam (heterogen) sehingga program-program kerja disesuaikan dengan kondisi dan potensi yang ada sesuai bidang, baik di bidang Pendidikan, Ekonomi, Hukum, Kesehatan, Agama Islam, dan Teknik. Ekonomi merupakan salah satu faktor penting yang dapat mempengaruhi kehidupan masyarakat Desa Mekar Jaya, ditemukan beberapa masalah di antaranya kurangnya kesadaran akan pentingnya melakukan pencatatan pembukuan dalam wirausaha dan kurangnya keinginan untuk berinovasi dalam penjualan produk yang dihasilkan. Dalam mengatasi masalah ini kami mengadakan Pelatihan Membuat Pencatatan dan Laporan Keuangan dalam berwirausaha yang merupakan salah satu solusi untuk meningkatkan pengetahuan masyarakat dalam mengembangkan usaha yang inovatif serta berpeluang mendapatkan profit. Hasil yang di capai adalah mengembangkan potensi ekonomi untuk berwirausaha yang inovatif.
\end{abstract}

Kata kunci : Pengembangan ekonomi, Kesadaran berwirausaha, pencatatan pembukuan.

\section{PENDAHULUAN}

Desa Mekarjaya adalah salah satu desa yang berada di wilayah Kecamatan Cigudeg Kabupaten Bogor, Provinsi Jawa Barat. Secara umum keadaan geografis Desa Mekarjaya merupakan daerah dengan total luas tanah $728,00 \mathrm{Ha}$, terdiri atas tanah sawah seluas 172,00 Ha. Selain itu terdapat pula tanah kering seluas $55,50 \mathrm{Ha}$ dengan rincian 50,00 Ha pemukiman, dan 5,50 Ha pekarangan. Desa Mekarjaya memiliki 4 dusun, yang terdiri dari 9 RW dan 34 RT. 


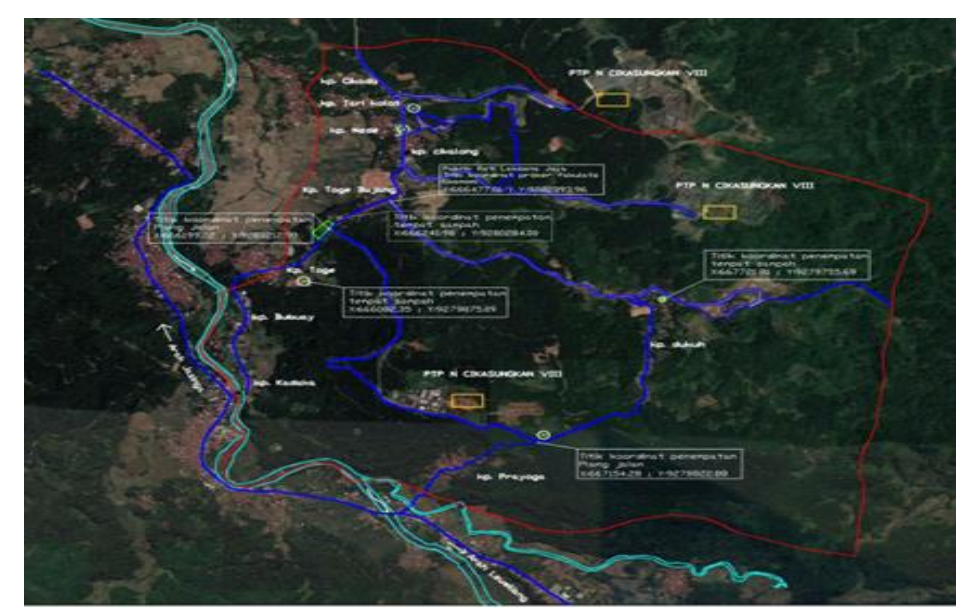

Gambar 1. Lokasi Desa Mekarjaya Kecamatan Cigudeg Kabupaten Bogor

Dilihat dari topografi Desa Mekarjaya merupakan potensi daerah dengan potensi mata air sedang. Sumber air bersih Desa Mekarjaya bersumber dari sumur galian dengan jumlah 950 unit sumur untuk dimanfaatkan oleh $1650 \mathrm{KK}$. Kualitas air minum di Desa Mekarjaya pun terbilang baik, dengan rincian tidak berwarna dengan sedikit bau zat besi.

Penduduk Desa Mekarjaya dengan jumlah penduduk 7065 jiwa sampai

\begin{tabular}{|l|l|l|}
\hline No & Jenis pekerjaan & Jumlah \\
\hline 1 & Petani & 39 orang \\
\hline 2 & Buruh tani & 420 orang \\
\hline 3 & Pegawai Negeri Sipil & 14 orang \\
\hline 4 & Pengrajin & 65 orang \\
\hline 5 & Guru swasta & 20 orang \\
\hline 6 & Pedagang keliling & 150 orang \\
\hline 7 & Pengrajin & 65 orang \\
\hline 8 & Guru swasta & 20 orang \\
\hline 9 & Pedagang keliling & 150 orang \\
\hline 10 & Pembantu rumah tangga & 25 orang \\
\hline 11 & Karyawan perusahaan swasta & 240 orang \\
\hline 12 & Wiraswasta & 125 orang \\
\hline 13 & Perangkat desa & 12 orang \\
\hline 14 & Buruh harian lepas & 1095 orang \\
\hline 15 & Sopir & 160 orang \\
\hline 16 & Pemulung & 10 orang \\
\hline
\end{tabular}

Berdasarkan tabel diatas, jumlah pekerjaan yang terbesar adalah petani, dengan bulan desember 2018, dengan jumlah Kepala Keluarga (KK) sebanyak 1650 KK, dan kepadatan penduduk 970,47 perKM. Peningkatan dan penurunan laju pertumbuhan ekonomi (LPE) masyarakat berpengaruh secara tidak lansung ke dalam peningkatan kesejahtaraan masyarakat. Adapun mata pencaharian masyarakat dilihat pada tabel berikut : 
kelapa sawit di daerah Desa Mekarjaya. Permasalahan di Desa Mekarjaya adalah bidang ekonomi dalam hal kurangnya kesadaran akan pentingnya melakukan pencatatan pembukuan dalam wirausaha dan kurangnya keinginan untuk berinovasi dalam penjualan produk yang dihasilkan. Dilihat pada data kualitas angkatan kerja di desa Mekarjaya pada tahun ini untuk sumber daya yang sudah bekerja sebanyak
1088, namun, untuk jumlah pengangguran yaitu sebanyak 1136 orang. Dengan permasalahan tersebut, kami anggota KKN 39 dan 40 yang ditempatkan di Desa Mekarjaya mengadakan sosialisasi kewirausahaan dan pencatatan laporan keuangan di Pabrik Roti Laksana jaya yang dikembangkan oleh Bapak Mamat Ruhayat.

\section{METODE PENGABDIAN}

Tahapan pelaksanaan untuk kegiatan ini sebagaimana terlihat pada bagian sebagai berikut :

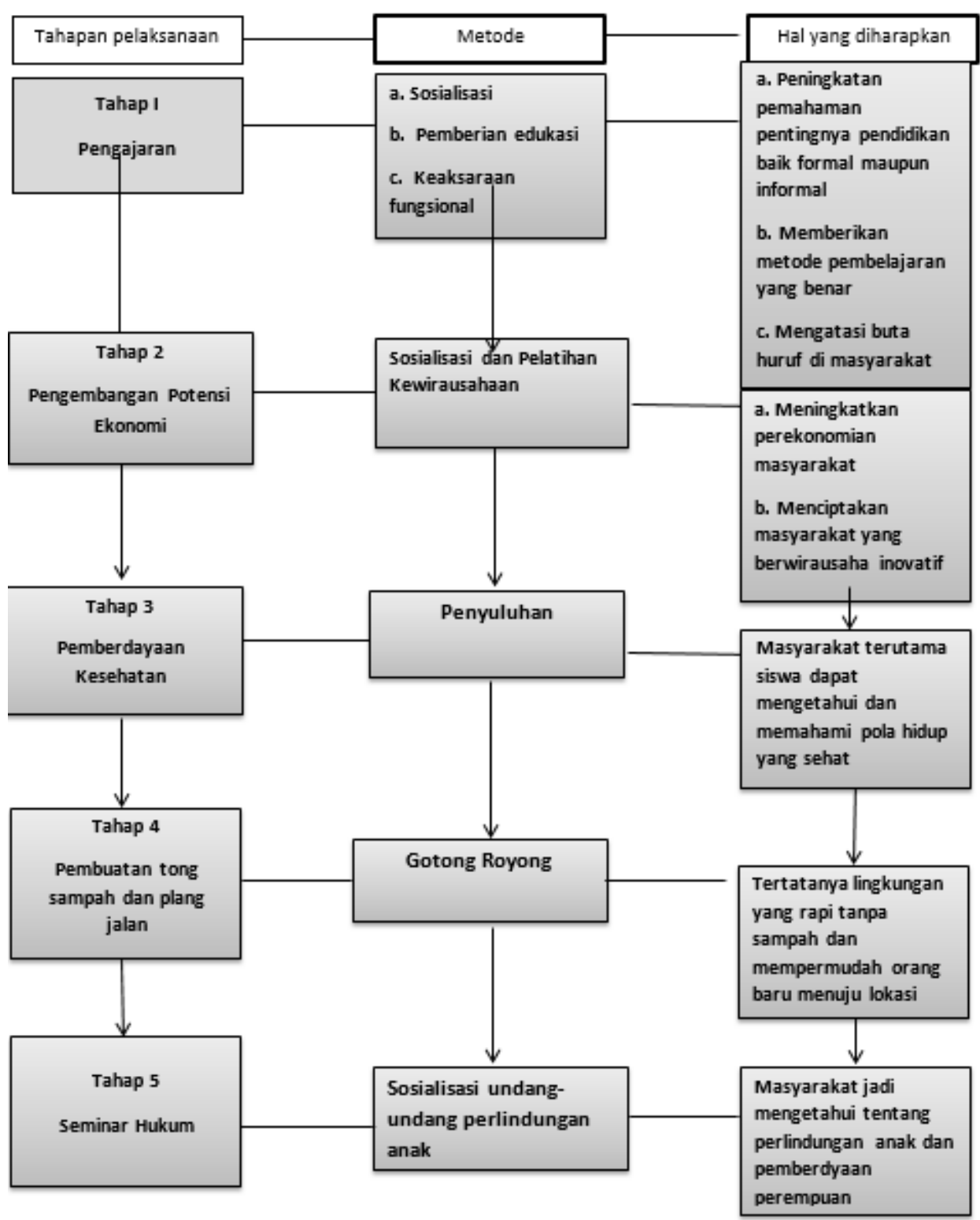




\section{Metode Pendekatan}

Pendekatan yang digunakan dalam kegiatan ini dalam $\mathrm{KKN}$ ini yaitu dengan pendekatan sosial. Pendekatan sosial merupakan hal yang amat penting untuk dilakukan guna menunjang keberhasilan KKN. Oleh karena itu, penyelenggaraan KKN perlu didasari oleh pendekatan sosial yang tepat dan memadai, baik pada saat perencanaan, pelaksanaan, maupun pada tahap evaluasi.

Pendekatan sosial dilakukan melalui tahapan-tahapan yang sistematis, meliputi tahapan:

\section{Pembukaan Hubungan}

Dalam tahapan ini mahasiswa beserta dosen pembimbing dapat mengadakan diskusi atau lokakarya dengan semua pihak strategis di masyarakat tentang rencana kerja.

\section{Pemeliharaan Hubungan}

Hubungan yang telah terjalin melalui tahapan sebelumnya, selanjutnya perlu dipelihara dan dijaga agar suasana KKN tetap berjalan kondusif. Dalam pemeliharaan hubungan, komunikasi informal dapat memberikan hasil yang jauh lebih efektif.

3. Pembinaan Hubungan

Pembinaan hubungan terutama dilaksanakan oleh pengelola $\mathrm{KKN}$ (lembaga atau tim yang ditunjuk oleh perguruan tinggi yang bersangkutan) pada saat mengadakan pemantauan (monitoring) dan evaluasi terhadap rencana dan pelaksanaan kegiatan yang telah disetujui pihak-pihak strategis. Pada tahap ini dapat terjalin hubungan kerja.

sama antara Perguruan Tinggi dengan masyarakat yang tidak hanya sebatas KKN.

\section{Mengakhiri Hubungan}

Pada tahap ini peserta KKN berpamitan dengan masyarakat, baik secara formal maupun personal. Secara formal biasanya dilakukan secara seremonial dalam bentuk acara khusus pelepasan peserta KKN oleh masyarakat setempat..

\section{Partisipasi Masyarakat dalam Pelaksanaan Program}

Partisipasi masyarakat yang dapat dilakukan dalam kegiatan ini adalah sebagai berikut:

1. Menyediakan tempat tinggal bagi peserta KKN

2. Mempersiapkan tempat untuk pembinaan dan pelatihan.

3. Masyarakat bersama peserta KKN bersama-sama melaksanakan program untuk meningktkan taraf kesejahtaraan masyarakat

4. Pelaksanaan pengajian rutinan bersama peserta KKN

\section{Langkah Evaluasi}

Evaluasi yang akan di lakukan terdiri dari :

1. Evaluasi Proses yang terkait dengan perencenaaan, pelaksanaan dan monitoring kegiatan. Evaluasi proses akan dilakukan setiap kegiatan acara internal

2. Evaluasi hasil, yang dilakukan setiap kegiatan dilaksanakan. Evaluasi hasil ditujukan untuk menguji pemahaman masyarakat tentang pentingnya berwirausaha bisa tercapai. Selain itu, evaluasi hasil akan di tujukan pada terciptanya lapangan kerja

3. Evaluasi dampak, yang dilakukan setelah pelaksanaan pembinaan. 


\section{REALISASI PROGRAM}

Program kerja utama Kuliah Kerja Nyata (KKN) Kelompok 39 dan 40 adalah Pentingnya berwirausaha dan membuat buku laporan keuangan di Kp. Toge Tonggoh Desa Mekarjaya Kecamatan Cigudeg, Kabupaten Bogor.

\section{Program yang dilaksanakan}

Program unggulan merupakan program utama yang diajukan oleh anggota kelompok 39 dan 40 di bidang ekonomi dan didampingi oleh dengan program lain sebagai program kegiatan non tema yang memiliki peran penting dari program unggulan.

\section{Bidang Pendidikan}
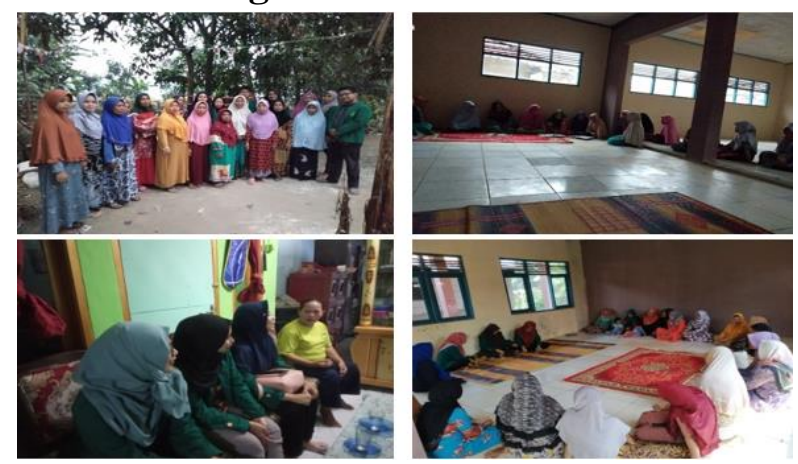

a. Keaksaraan Fungsional

Buta aksara dapat menghambat kegiatan penduduk sehingga perlu diadakannya kegiatan yang dapat melatih penduduk dalam mengenali dan memahami aksara.

Sasaran kegiatan ini adalah ibu-ibu di RW. 01 Kp. Tari Kolot, yang mana bertujuan untuk memberantas buta aksara Al-Qur'an. Dilaksanakan pukul $16.00 \mathrm{~s} / \mathrm{d}$ 17.00 WIB yang bertempat di Kediaman Ibu RW. 01 dan gedung serbaguna. Rangkaian dari kegiatan ini diantaranya adalah belajar membaca al-qur'an bersama, belajar makhrajil huruf, dan ilmu tajwid.
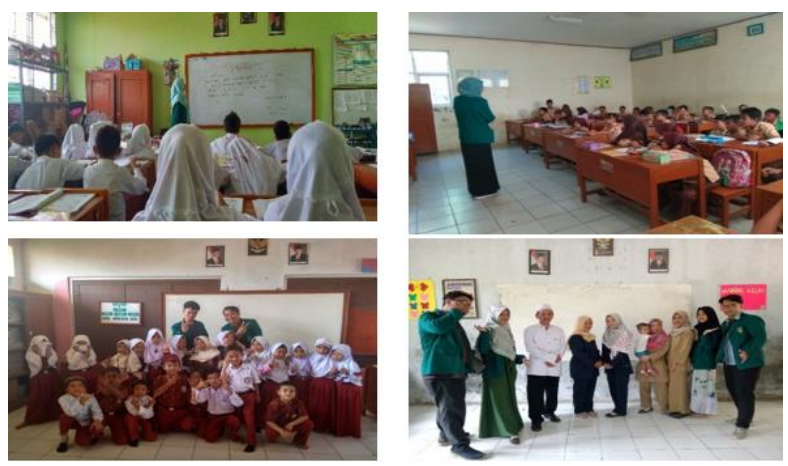

b. Pengajaran

Tenaga pendidik merupakan salah satu faktor penting dalam kegiatan pembelajaran. Kurangnya tenaga pendidik dan fasilitas yang memadai pada empat sekolah dasar dan satu madrasah ibtidaiyah di desa Mekarjaya merupakan latar belakang berjalannya program ini. Dengan penggunaan beragam media pembelajaran seperti poster, video conversation, flashcards dan variasi metode pembelajaran seperti task based language learning, cooperative learning, dan project based learning, kegiatan ini berlangsung di hari sekolah, pada pukul 07.00 s/d 11.30 WIB yang bertempat di SD Bunar 02, SD Bunar 04, SD Bunar 01, SD Dukuh dan MI Mathlaul Anwar.
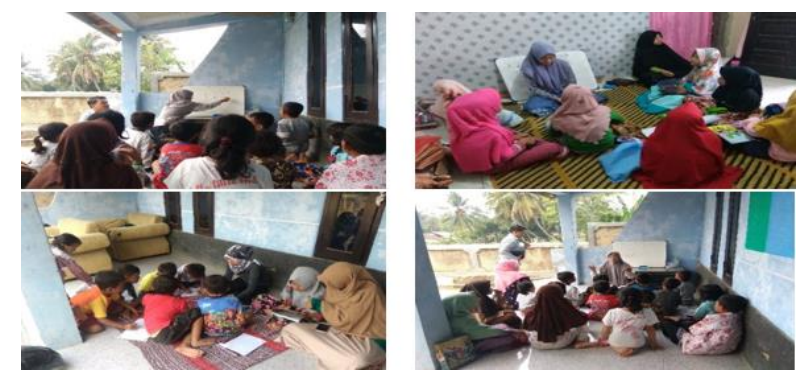

c. Rubela

Banyaknya waktu luang yang dimiliki oleh anak-anak di sekitar posko 39 - 40 menjadi latar belakang berjalannya program ini. Maka dari itu, untuk mengatasi masalah tersebut, kami membuat program belajar yang dinamakan RUBELA (Rumah Belajar) yang diadakan di Posko. Mata pelajaran yang diajarkan diantaranya adalah Matematika, Bahasa 
Inggris, Bahasa Indonesia, Agama, dan Kreatifitas. Kegiatan ini berlangsung pada pukul 16.00 - 17.30 pada hari Senin s/d Sabtu.

\section{Bidang Ekonomi}
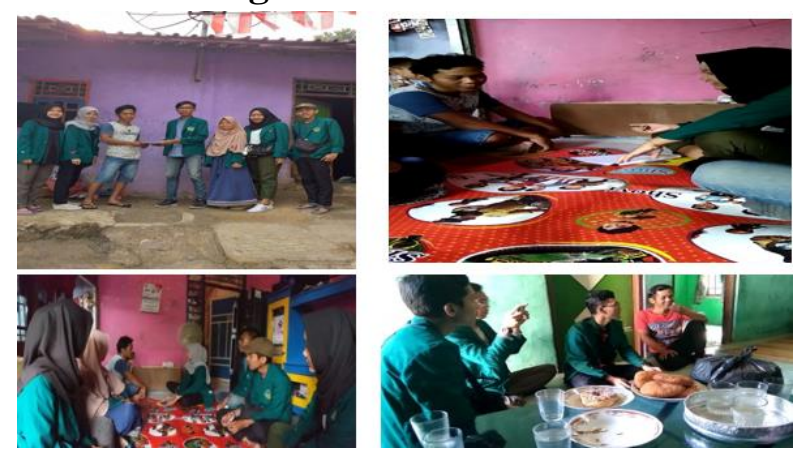

a. Pelatihan Membuat Pencatatan dan Laporan Keuangan

Sistem pembukuan menjadi sarana vital dalam wirausaha. Dengan sistem pembukuan, pemilik usaha dapat melakukan kalkulasi, mengontrol serta mengatur keseluruhan transaksi keuangan yang terjadi sepanjang keberlangsungan dunia usahanya. Kegiatan ini berlangsung di Pabrik Roti Laksana Jaya yang berdiri sejak tahun 2008 dikembangkan oleh Bapak Mamat Ruhiyat. Bapak Mamat Ruhiyat memiliki beberapa karyawan, namun, proses pembuatan dan penjualannya masih sangat tradisional dan sederhana juga dalam perhitungan keuangannya pun tanpa laporan keuangan. setiap bulan atau pertahunnya. Maka dari itu kami memberikan solusi untuk mengenalkan bagaimana cara membuat pembukuan laporan keuangan sederhana. Kegiatan ini berlangsung pada Jum'at, 16 Agustus 2019.
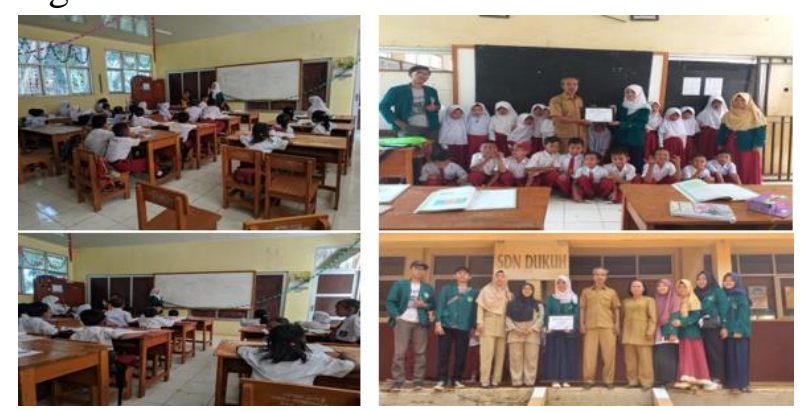

b. Sosisalisasi Kewirausahaan dan Pentingnya Menabung Sejak Dini

Anak-anak yang mengenal dunia wirausaha sejak dini, akan mendapati manfaat untuk bekal masa depan kelak. Pada tahapan usia yang terbilang belia, anak-anak yang belajar menumbuhkan jiwa wirausaha, akan tumbuh menjadi pribadi yang kreatif. Kegiatan ini berlangsung di SD Dukuh pada selasa, 20 Agustus 2019.
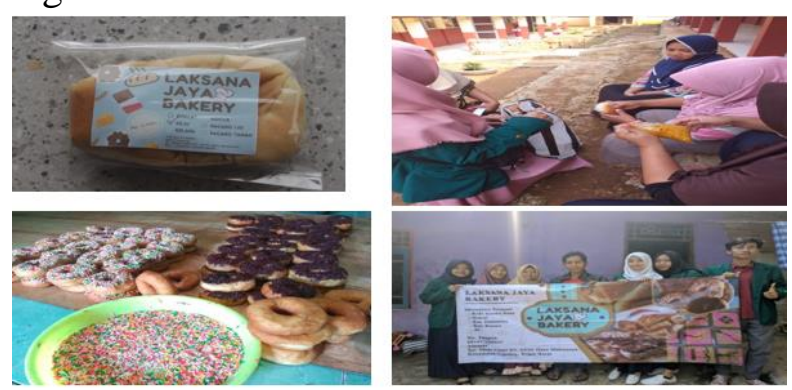

c. Ekonomi Kreatif Penjualan roti dan donat dengan kemasan dan logo buatan mahasiswa

Menjualkan roti dan donat dengan warga dan anak-anak sekolah sebagai sasaran dengan harga mulai dari Rp. 2.000.00,- sampai Rp. 5.000.00,- yang sudah dikemas dan diberi logo hasil kreatifitas mahasiswa untuk menarik konsumen atau pembeli karena sebelumnya roti dan donat dijual tidak menggunakan logo atau merk. Kegiatan ini berlangsung pada Senin, 26 Agustusan 2019

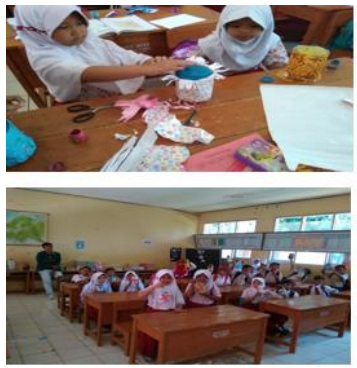

d. Lomba Menghias Calengan dalam rangka memperingati 17 Agustus

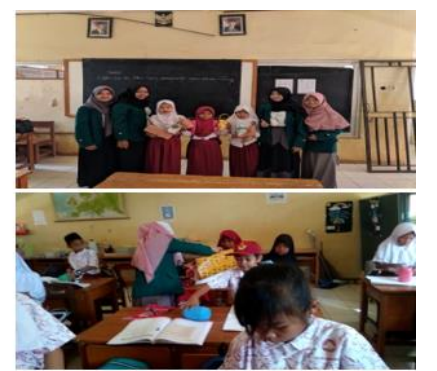

\section{7}


Umumnya, kreatifitas siswa siswi banyak pada bidang seni dituangkan pada mata pelajaran kesenian di sekolah. Perlombaan menciptakan sesuatu melalui seni diyakini dapat memacu potensi siswa siswi dalam pembelajaran sehari hari. Kegiatan ini bertujuan untuk meningkatkan kreatifitas siswa-siswi agar lebih giat menabung sejak dini juga kegiatan ini dilakukan dalam rangka HUT RI ke 74 tahun. Kegiatan ini dilaksanakan pada Rabu, 21 Agustus 2019

\section{Bidang Keagamaan}

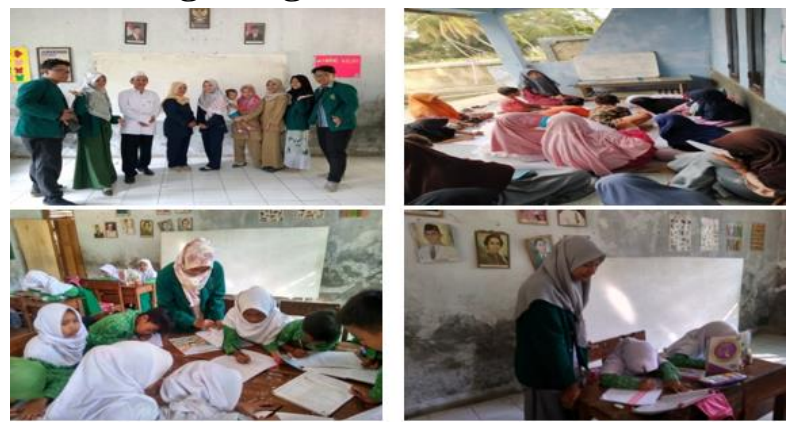

a. Literasi bahasa arab

Literasi bahasa arab ini dilakukan guna meningkatkan pemahaman anak-anak mengenai cara membaca tulisan arab dengan baik dan benar, serta memperkenalkan sedikit demi sedikit bahasa arab yang mudah dihafal dan dipahami oleh anak-anak usia dini. Literasi bahasa arab ini dilakukan di MI Mathlaul Anwar dan juga pada kegiatan bimbel rutin yang dilakukan langsung di posko 40 yang berada di Kp. Toge RW 05.
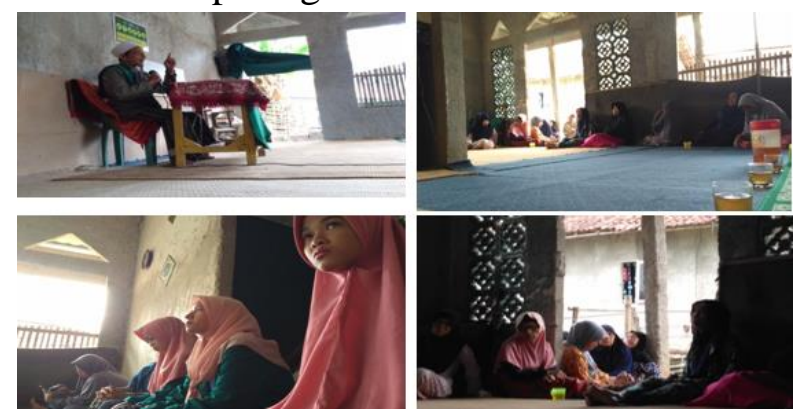

b. Pengajian Ibu-ibu

Pengajian ibu-ibu di Desa Mekarjaya rutin dilakukan setiap hari di tiap-tiap RW, salah satunya di Majlis Ta'limi9oi9o t[zajh k Nurul Huda yang berada di RW 05 yang rutin dilakukan setiap Selasa di waktu sore hari. Pembahasan yang dibahas dalam Majlis Ta'lim Nurul Huda begitu beragam dan berkaitan dengan kehidupan masyarakat sehari-hari agar menjadi lebih mudah dicerna dan diaplikasikan dalam kehidupan masyarakat setempat. Mahasiswa ikut serta dalam menghadiri pengajian tersebut guna terus menjalin silaturahmi dengan masyarakat sekitar.
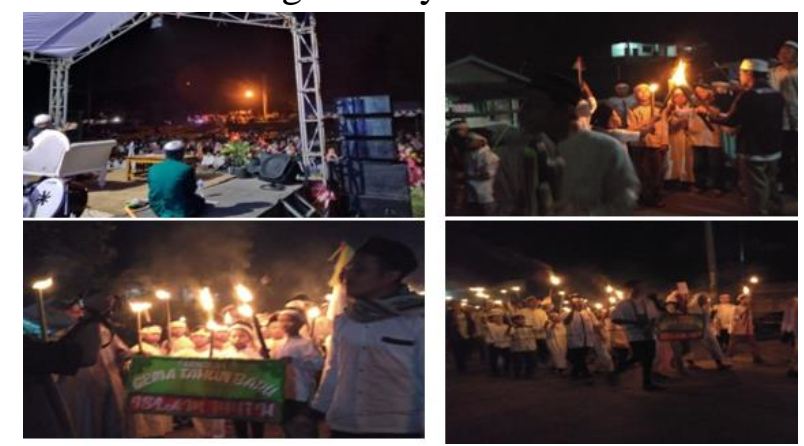

c. Tabligh akbar dan pawai obor

Acara pawai obor dan tabligh akbar ini diselenggarakan dalam memperingati tahun baru Hijriyah $1441 \mathrm{H}$ dan melibatkan seluruh masyarakat Desa Mekarjaya maupun masyarakat diluar Desa Mekarjaya. Antusiasme masyarakat begitu sangat terasa pada saat satu persatu penampilan pawai obor per-RW dimulai. Sekitar 1500 orang peserta hadir dan ikut serta dalam memeriahkan pawai obor dan tabligh akbar tersebut. Acara ini dimaksudkan untuk terus menjalin ukhuwah antar masyarakat dan terus membangkitkan semangat juang dan jihad masyarakat pada era modern seperti sekarang ini. 
4. Bidang Kesehatan

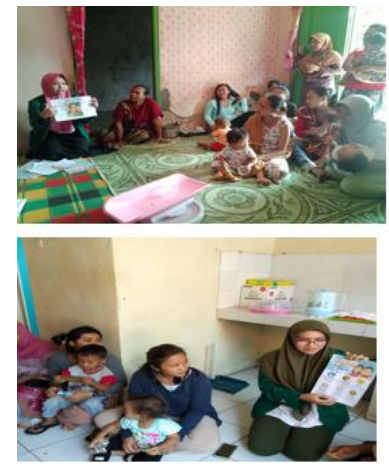

a. Kegiatan

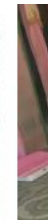
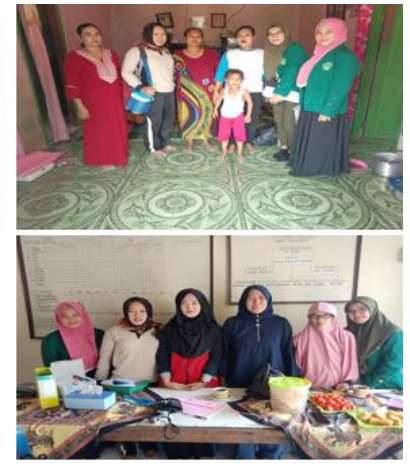

Posyandu dan

Penyuluhan Gizi pada Bayi dan Balita

Posyandu menjadi sarana untuk mengetahui keadaan gizi bayi dan balita, memberikan vitamin, dan memberikan imunisasi. Maka dari itu penyuluhan gizi baik untuk bayi dan balita perlu di sosialisasikan untuk menyadarkan para ibu agar selalu berkunjung ke posyandu satu kali setiap bulan sesuai waktu yang di tentukan. Kurangnya kesadaran akan pentingnya kunjungan ke posyandu menjadi latar belakang dilaksanakannya program ini. Kegiatan ini berlangsung pada Sabtu, Sabtu, 10 Agustus 2019 dan berlokasi pada di Kampung Dukuh Rw 08 serta di posyandu Anggrek Mes Kelapa sawit.
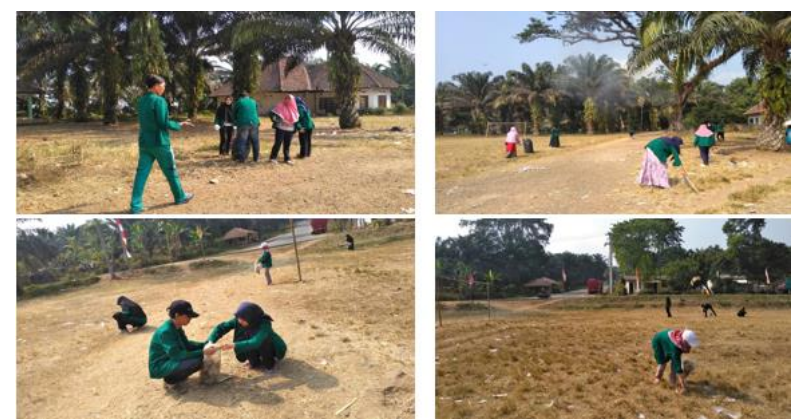

b. Kerja Bakti

Pada umumnya sebagian besar masyarakat masih lalai terhadap kebersihan lingkungan sekitarnya. Maka dari itu perlu di bangun kesadaran masyarakat untuk menjaga kebersihan lingkungannya sendiri. Perlunya contoh untuk membangun kesadaran masyarakat.
Dimulai dari mahasiwa yang memberikan contoh gotong royong kepada masyarakat. Perlunya diadakan kerja bakti untuk menyadarkan masyarakat akan pentingnya gotong royong demi menciptakan lingkungan yang bersih dan sehat merupakan latar belakang dari terlaksananya program ini. Kegiatan ini berlangsung pada Senin, 12 Agustus 2019 dan berlokasi di lapangan PTP samping kantor desa Mekarjaya
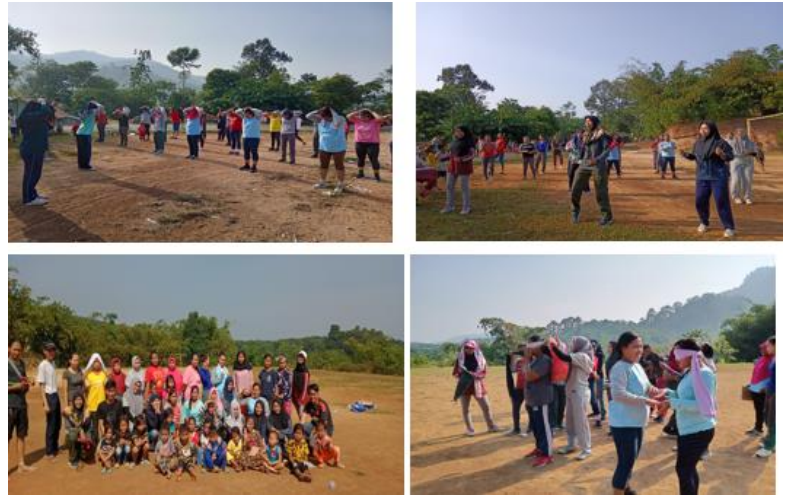

c. Senam sehat ceria bersama ibuibu

Saat ini kita dihadapkan pada keadaan zaman yang serba modern, kurangnya aktifitas masyarakat membuat penyakit mudah muncul, maka dari itu mahasiswa memperkenalkan senam sehat ceria di kalangan ibu-ibu dan remaja agar masyarakat bisa beolahraga dengan gembira, dan sadar akan pentingnya olahraga. Maka dari itu, perlu adanya kebiasaan berolahraga bagi masyarakat. Kegiatan ini berlangsung pada Minggu 1 september 2019 yang berlokasi pada lapangan kampung Dukuh RW 08 

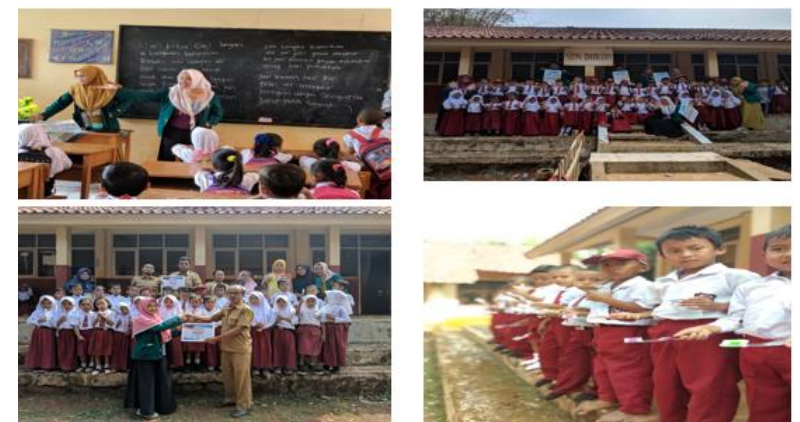

d. Penyuluhan PHBS (Perilaku Hidup Bersih dan Sehat) dan Penyuluhan Kesehatan Gigi dan Mulut

Siswa-siswi disekolah dasar banyak yang belum menyadari pentingnya cuci tangan dan sikat gigi secara teratur. Maka dari itu mahasiswa memberikan penyuluhan dan praktek bersama secara sederhana dengan harapan siswa-siswi bisa menerapkan di kebiasaan sehari-harinya. Maka dari itu kebiasaan berPHBS (prilaku hidup bersih dan sehat) di ligkungan sekolah perlu di bangun. Kegiatan ini berlangsung pada Senin s/d Selasa, 26 - 27 Agustus 2019.

\section{Bidang Teknik}
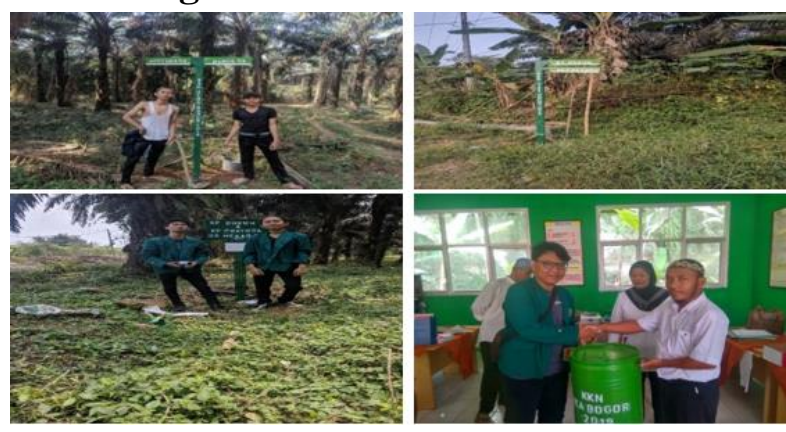

a. Proses Pembuatan Tempat

Sampah Dan Penunjuk arah

Program Pembuatan dan penyediaan tempat sampah ,sebagai untuk memfasilitasi adanya tempat sampah untuk menumbuhkan pentingnya kesadar.an pembuangan sampah pada tempat nya yang nantinya akan bersifat baik bagi prilaku sejak dini untuk kedepanya agar tidak membuang sampah sembarangan seperti ke kali, pinggir jalan, solokan yang apat meyebabkan banjir di kemudian hari didesa. Progrsm penunjuk arah bertujuan untuk Untuk memberi informasi arah tentang daerah sekitar agar memudahkan warga/ pendatang baru untuk mengetahui letak/ nama kampung di desa Mekarjaya selain itu kami sebagai mahasiswa UIKA juga memberikan pengarah ke arah masjid dan desa untuk senantiasa memberikan pengarahan ke arah masjid untuk sholat berjamaah. Penyerahan Tempat Sampah dan penunjuk arah tersebar di wilayah Desa Mekarjaya dan sekolah sekolah yang membutuhkan. Untuk penyerahan tempat sampah di serahkan pada SDN Bunar 04, SDN Dukuh dan, MI Mathlaul Anwar. Dan untuk penunjuk arah di sebarkan dibeberapa titik desa Mekar Jaya.
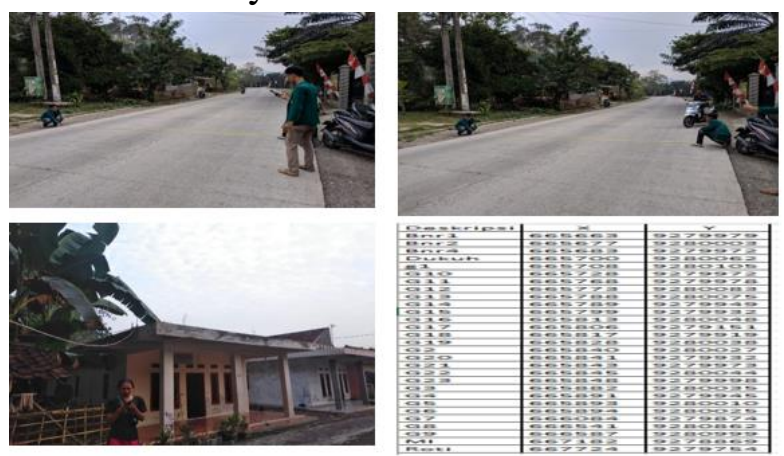

b. Mengukur Jalan dan Mapping

Kegiatan ini dilaksanakan bertujuan untuk mengetahui ukuran jalan utama desa Mekarjaya, dan membuat denah lokasi kegiatan kami selama KKN , seperti sekolah, home industri makanan, madrasah, penempatan tempat sampah dan pembuatan penunjuk arah. 

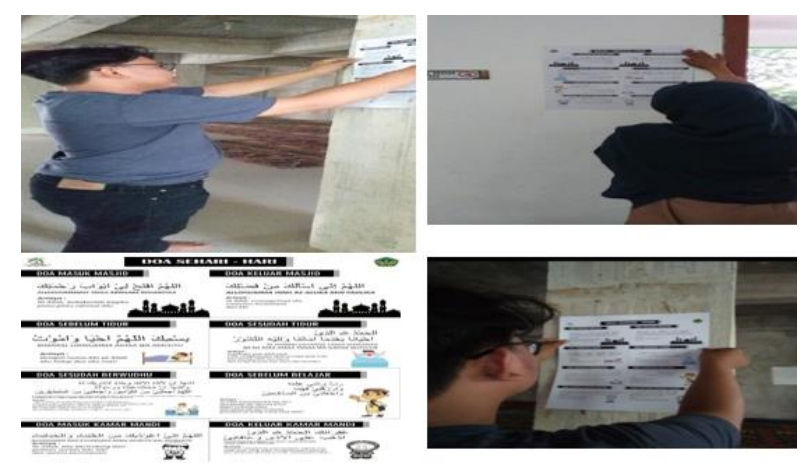

c. Poster PHBS dan Doa-Doa masuk Masjid

Program ini bertujuan untuk memberikan pemahaman kepada warga desa mekarjaya tentang tata cara masuk masjid, doa-doa harian dan memcuci tangan yang baik dan benar. Kegaiatan ini yaitu menyebarkan pamflet pamflet di sekolah dan masjid di sekitar Desa Mekarjaya .
6. Bidang Hukum
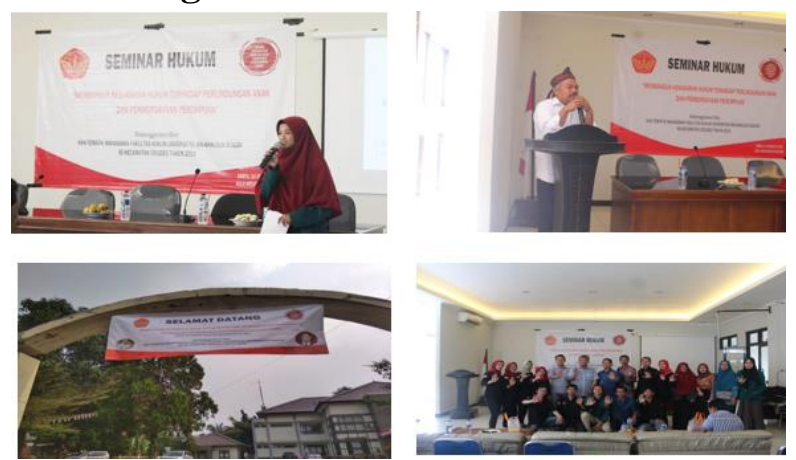

A .Seminar Hukum

Kegiatan ini dilaksanakan di aula kecamatan Cigudeg Tanggal 24 Agustus 2019 jam 10.00 di hadiri oleh 69 peserta dari kalangan ibu-ibu PKK,tokoh masyarakat, Polsek Cigudeg, KNPI dan mahasiswa yang sedang KKN di Kecamatan Cigudeg. Kegiatan ini bertema yaitu "Membangun Kesadaran hukum terhadap perlindungan anak dan Pemberdayaan perempuan“ dengan Narasumber yaitu Bapak Dr.Ibrahim Fajri,S.H,MEI dan Dudih Syiaruddin (Ketua KPAI Kota Bogor) Kegiatan ini bertujuan untuk memberi pemahaman hukum kepada warga desa sekecamatan cigudeg terhadap anak dan perempuan karena kasus di desa Mekarjaya yaitu adanya KDRT dan hamil diluar nikah. Pentingnya sosialisasi UU Perlindungan anak pasal 20 UU 35 Tahun 2014.

\section{KESIMPULAN}

Kuliah Kerja Nyata merupakan salah satu kegiatan Universitas untuk merealisasikan tridharma perguruan tinggi yaitu pengabdian pada masyarakat. Kegiatan ini dilaksanakan selama 30 hari dengan program program yang setiap 6 fakultas melaksanakannya..Desa Mekarjaya memiliki potensi yang banyak, terutama di bidang Pendidikan dan Majlis Talim. Namun, fasilitasnya belum memadai, kurangnya akses informasi dalam pentingnya pendidikan.Maka peran mahasiswa dalam masyarakat ini adalah menjalankan program kerja yang sesuai untuk meningkatkan potensi Desa Mekarjaya.

Berdasarkan uraian program yang dipaparkan pada bab sebelumnya selama kegiatan KKN di Desa Mekarjaya Kecamatan Cigudeg Kabupaten Bogor, berikut kami paparkan beberapa kesimpulan yang kami peroleh: 
1. Terealisasinya program-program kerja KKN 2019 Universitas Ibn Khaldun sebagai upaya pengabdian kepada masyarakat di desa Mekarjaya kecamatan Cigudeg kabupaten Bogor.

2. Terbentuknya kepedulian yang tinggi terhadap permasalahan di desa Mekarjaya dan sosialisasi yang baik antara para mahasiswa 39 dan 40 yang mengikuti program KKN dengan warga setempat.Maka dari itu hasil dari program kegiatan Kuliah Kerja Nyata (KKN) cukup memberi dampak dan pengaruh yang signifikan bagi masyarakat khususnya di Desa Mekar Jaya . Program kelompok 39 dan 40 tidak selalu di satu RW tetapi diseluruh wilayah dari RW 01 sampai RW 09 Desa Mekarjaya. Kuliah Kerja Nyata merupakan sarana bagi mahasiswa untuk menyalurkan potensi sebagai agen perubahan dan pemberi solusi pada setiap permasalahan dimasyarakat.program yang dilaksanakan di masyarakat selama KKN terdiri dari 6 bidang diantaranya, Bidang Agama, Bidang Pendidikan, Bidang kesehatan, Bidang ekonomi, bidang teknik dan bidang hukum.

a. Bidang agama, memberikan semangat dan pemahaman kepada seluruh warga Desa Mekarjaya Kecamatan cigudeg dalam menyebarkan syariat-syariat Islam. Program yang kami terapkan yaitu mengutamakan ukhuwah islamiyah dan membangkitkan semangat hijrah. Selain itu, materi tentang pentingnya belajar bahasa arab, rukun iman dan islam serta rukun-rukun shalat wajib juga kami berikan kepada anak-anak desa Mekarjaya utamanya di KP.Toge Tonggoh. b. Bidang Pendidikan, memberikan semangat dan motivasi kepada anakanak Desa Mekarjaya dalam belajar ilmu pengetahuan umum. Pada program Rubela yang memiliki tujuan untuk membantu anak-anak di Desa Mekarjaya dalam bimbingan belajar di luar sekolah dan bermanfaat untuk meningkatkan pemahaman dan kesadaran akan pentingnya belajar, belajar berbahasa asing dan belajar untuk menjadi anak-anak yang percaya diri dan berpikir kritis.

c. Bidang Kesehatan, Memberikan sosialiasai kepada masyarakat untuk memahami dan selalu menjaga kesehatan dengan mengatur pola hidup sehat sehari-hari.

d. Bidang Ekonomi, memberikan pemahaman tentang pentingnya berwirausaha serta memberikan cara penjualan roti dan donat dengan aksi turun lansung ke sekolah-sekolah berjualan. Dengan pelatihan dan sosialisasi ini dapat menjadi wawasan dan inovasi warga untuk membuka usaha home industri dengan menarik konsumen atau pembeli karena sebelumnya roti dan donat dijual tidak menggunakan logo atau merk.. karena dengan berwirausaha itu akan mengurangi angka pengangguran.

e. Bidang Teknik, Sebagian besar penduduk di Desa Mekarjaya Kecamatan Cigudeg Kabupaten Bogor masih minim tempat sampah terutama di sekolah-sekolah selain itu tidak adanya papan penunjuk arah. Maka dari itu, kami membantu masyarakat untuk menyediakan tempat sampah membuang sampah pada tempatnya dan penunjuk arah 


$$
\begin{aligned}
& \text { memudahkan pendatang untuk } \\
& \text { datang ke kampung di Desa } \\
& \text { MekarJaya }
\end{aligned}
$$
f. Bidang Hukum, memberi pemahaman tentang kesadaran hukum perlindungan anak dan pemberdayaan perempuan agar tidak adanya eksploitasi anak dan KDRT pada perempuan.

g. Partisipasi dalam kegiatan 17 Agustusan dengan bersama-sama mengecat gapura dan mengadakan

\section{SARAN}

Berdasarkan Kegiatan yang telah dilaksanakan oleh mahasiswa KKN kelompok 39 dan 40 Universitas Ibn Khaldun Bogor yang dilaksanakan di Desa Karacak tepatnya di Kp. Toge Tonggoh Kecamatan Cigudeg Kabupaten Bogor, kami Peserta KKN memberikan beberapa hal sebagai saran untuk perkembangan program kerja kami selanjutnya :

1. Perlu adanya kerja sama dan dukungan yang baik dari perangkat desa setempat dengan masyarakat dalam rangka meningkatkan segala potensi di Desa Karacak guna meningkatkan kesejahteraan hidup masyarakat.

2. Saling bekerjasama antar pihak terkait, baik aparat desa, rw, rt, dan masyarakat. perlombaan di desa, kp.Toge Tonggoh dan sekolah-sekolah yang di Desa MekarJaya yang diharapkan dapat meningkatkan rasa Nasionalisme kita terhadap bangsa Indonesia sekaligus sebagai rasa syukur serta mengenang jasa-jasa pahlawan terdahulu. Selain itu juga sebagai sarana untuk meningkatkan solidaritas bagi warga Desa Mekarjaya untuk lebih mempererat tali persaudaraan.

3. Partisipasi masyarakat setempat untuk ikut serta menjaga dan melanjutkan program-program yang telah dijalankan mahasiswa.

4. Perlu adanya dukungan dalam meningkatkan kreatifitas masyarakat dalam mengolah SDM dan mengembangkan SDA yang ada.

5. Pemberian dukungan penuh dalam bentuk moral maupun moril dari warga desa setempat.

6. Harus mampu merealisasikan progampogram khususnya dalam bidang agama, pendidikan, ekonomi, kesehatan, agama, teknik dan hukum. 


\section{DAFTAR PUSTAKA}

Cahyo, Herman (2018). Pengembangan wilayah pedesaan berbasis pada potensi sumber daya Alam di Kabupaten Bondowoso. Vol.18 no.2

Fathimah, A., Agnesia, U., dan Abdul, R. (2019). Pemberdayaan Masyarakat melalui peningkatan Mutu Pendidikan, Ekonomi dan Kesehatan Studi Kasus Cibeber II. Abdi Dosen: Jurnal Pengabdian Pada Masyarakat 3 (1), 1-7.

Fersandi, Pradika. (2016). Pengembangan potensi ekonomi lokal desa tosari kabupaten pasuruan. Universitas PGRI Adi Buana Pasuruan.

Husna, Nailatul. (2013). Analisis pengembangan potensi ekonomi lokal untuk menguatkan daya saing daerah di Kabupaten Gresik.vol 1 no. 1
http://pkm.uikabogor.ac.id/index.php/BDI DOS/issue/archive

Malinda, Yola. (2014). Analisis Potensi Ekonomi Daerah dalam Pengembangan Komoditi Unggulan Kabupaten Agam. STKIP PGRI Sumatera Barat.

Mulyawan, Iwan. (2014). Potensi ekonomi dan arahan pengembangan perekonomian wilayah di desa-desa penyangga taman nasional ujung kulon.Institut Pertanian Bogor.

Profil Desa Mekarjaya (2018). Profil Desa Mekarjaya

Panitia KKN UIKA Bogor. 2019. Petunjuk Pelaksanaan KKN Tematik Terintegrasi 2019. Bogor: UIKA Press 